\author{
V.S. Portnov ${ }^{1}$, S.A. Vizhva ${ }^{2}$, N.V. Reva ${ }^{2}$, A.D.Maussymbayeva ${ }^{1}$, V.M. Yurov ${ }^{3}$ \\ ${ }^{1}$ Karaganda State Technical University, Kazakhstan; \\ ${ }^{2}$ T. Shevchenko Kiev National University, Ukraine; \\ ${ }^{3}$ Ye.A. Buketov Karaganda State University, Kazakhstan \\ (E-mail: exciton@list.ru)
}

\title{
Physical properties and forecasted resources of Shubarcol coal deposit
}

\begin{abstract}
At the presented work was described the method of estimating the forecasted reserves of mineral deposits. A general formula is proposed that relates the differentiated reserves of a mineral with its physical properties. As a physical value, both the results of geophysical exploration methods and measurements in laboratory conditions on core samples and formation samples can be used. Comparison of the reserves calculated by the proposed formula, but with different physical quantities, showed good accuracy of the proposed method. The method is used to estimate the reserves of the Shubarkol coal field, where the detailed geological exploration has not been carried out. The calculation gave total reserves of about 3 billion tons. The proposed method allows reducing the volume of geological exploration work and reducing the costs of their implementation.
\end{abstract}

Keywords: coal, deposit, forecasted reserves, gravity prospecting, electrical exploration, seismic exploration, mineral.

\section{Introduction}

One of the most common areas of quantitative assessment of promising metal reserves is the estimation based on the empirically established dependence of the reserves on the clarke of the corresponding element. For the first time this dependence was described by V. McKelvey, later it was studied in detail by L.N. Ovchinnikov [1]. The latter, on the example of several dozen metals, as well as boron, sulfur, phosphorus and fluorine, showed that there is a direct relationship between the cliché of the chemical element and its total world reserves in the ores of the deposits

$$
Q=k^{\prime} c_{0}
$$

where $c_{0}$ - average content of element in the earth's crust; $k^{\prime}$ - coefficient of proportionality.

The values of $k^{\prime}$ for these elements for continental depths of the order of $1.5-2 \mathrm{~km}$ are $k^{\prime}=(3.2 \pm 1.08) \cdot 10^{10}$ tons. The distribution of the values of $k^{\prime}$ is subject to normal law with a standard deviation of $3.07 \cdot 1010$. For depths of the order of 5-6 km, this coefficient is supposedly equal to $k^{\prime} \approx 1 \cdot 10^{11}$ tons. The presence of such a certain direct connection of the world's metal reserves in ores from its clark allows to obtain estimates of the indicated total reserves of it to depths of 2 or $6 \mathrm{~km}$. In those cases where the currently known reserves are significantly smaller than the estimate based on the average value of $k^{\prime}$, can expect their respective increment in the future.

For nonmetallic minerals, equation (1) is unsuitable for estimating the forecasted reserves of mineral deposits. In this connection, up to the present time, various approaches to solving this problem have been developed [2-5].

In this paper, we consider the use of physical properties of coal to assess its predicted reserves in the coal deposit Shubarkol.

\section{Estimation of predicted reserves of coal deposits}

In general, the estimation of the forecasted resources belongs to the category of research, rather than engineering, tasks. Resources divided into three categories in terms of their reliability. Forecasted resources of category $P_{3}$ take into account only the potential possibility of discovering deposits on the basis of certain geological and paleogeographic prerequisites. Resources of category $P_{2}$ take into account the possibility of discovering new deposits in the basin, the area, and category $P_{1}$ are based on the possibility of expanding the boundaries of the distribution of minerals beyond the already explored contours [6].

When choosing methods for estimating the forecasted resources, it is necessary to give preference to those that allow calculating resources using parameters obtained on the basis of direct observations and measurements (geological, geophysical, geochemical, etc.) with minimal use of certain assumptions. 
The most universal of these methods are estimation methods based on the use of analogies with standard ore objects (9) or with their generalized model and the varieties of these methods based on the use of regression or pattern recognition algorithms. In the absence of standards (in particular, fossils with predictable mineralization of new genetic or industrial types) methods of direct (standardless) estimation of the forecasted resources by calculations on the parameters of the medium and mineralization [7-9].

In the practice of calculating the reserves of all types of solid minerals, a single method of calculating reserves, called the geological block method, is used. Its essence consists in dividing the entire counting loop into a system of sections homogeneous by a group of parameters, called geological counting blocks. In this case, the number of stocks within each block can be determined using various methods. In the practice of exploration of coal deposits, two traditional methods are most common: the arithmetic mean and vertical cuts [6]. The essence of the method of the average arithmetic is that the complex body of a mineral, limited within the geological block under consideration from below and from above by geometrically irregular surfaces of topographical order, is transformed into an equal volume "plate», the area of which is equal to the area of the counting contour of the formation, the slope angle to the mean angle of fall of the formation, and the thickness corresponds to the average normal thickness of the formation. The method of vertical sections is used for conditions of complex dislocation deposits. When it is realized, the volume of minerals is determined between two geological sections. To do this, for each of the sections, the amount of coal within the vertically disposed plate having an area equal to the section of the formation in the cut plane and a thickness of $1 \mathrm{~m}$ is predetermined.

\section{Thermodynamic approach to estimating predictive resources}

In Refs. [10-12] we substantiated the thermodynamic approach in calculating the forecasted reserves of mineral deposits and obtained specific formulas, the generalization of which is the formula for differentiated reserves is

$$
P_{d}=\frac{1}{\ln (q A)} \cdot 100 \%
$$

In formula (2), the value of $\mathrm{A}$ is equal to: $\Delta g$ - anomaly of gravity (gravity prospecting); $\rho$ - specific electrical resistance (electrical prospecting); $\chi$ — magnetic susceptibility (magnetic prospecting); $v$ — speed of seismic waves (seismic prospecting), etc.

The coefficient q for each physical property A has a well-defined value. It is calculated by the method described by us in [10].

For example, for electrical reconnaissance methods, the constant $q=155121.6$. Table 1 presents calculations of the forecasted differentiated coal reserves of the main formations of the Karaganda coal basin.

T a b l e 1

Forecasted differentiated coal reserves of the main formations of the Karaganda coal basin

\begin{tabular}{|c|c|c|}
\hline Strata & $\begin{array}{c}\text { Resistivity constant, } \\
\rho(\mathrm{Ohm} \cdot \mathrm{m})\end{array}$ & $\begin{array}{c}\text { Differentiated stocks } \\
(\%)\end{array}$ \\
\hline Dolinskaya & 134,8 & 14,2 \\
\hline Tentekskaya & 155,0 & 14,5 \\
\hline Karagandinskaya & 145,1 & 14,3 \\
\hline Ashlyarikskaya & 86,7 & 13,4 \\
\hline
\end{tabular}

The Donetsk coal basin was opened in the 1720s near the present town of Lisichansk, Lugansk region. Industrial development began with the end of the XIX century. The area is about 60 thousand $\mathrm{km}^{2}$. Total reserves to a depth of $1800 \mathrm{~m}-140.8$ billion tons. In the coal-bearing strata of Carboniferous age, up to 300 strata; The average thickness of the working strata is $0.6-1.2 \mathrm{~m}$. Coals are of stone grades $D-T(78 \%)$, anthracites $(22 \%)$. The heat of combustion is $21.2-26.1 \mathrm{MJ} / \mathrm{kg}$. The main mining centers are Donetsk, Krasnoarmeysk, Makeyevka, Lisichansk, Gorlovka, Sverdlovsk, Rovenky, Anthracite, Torez, KrasnyiLuch and others.

Estimate under the formula (2) gives the value of the forecasted reserves for the Donetsk coal basin 460 billion tons. This overestimation shows that for coal basins as a whole, it is not advisable to calculate the average value of resistivity. This is due to the change in the latter in a very wide range. Therefore, for example, for anthracites the resistivity varies from $10-3$ to $10 \mathrm{Ohm} \cdot \mathrm{m}$. Therefore, the proposed method should 
be used for individual suites containing coals of the same brand and having approximately the same resistance.

Table 2 presents the results of calculating the forecasted resources of some coal deposits in Kazakhstan, where gravity prospecting was conducted.

T a b l e 2

\section{Forecasted and explored reserves of some coal deposits in Kazakhstan}

\begin{tabular}{|c|c|c|}
\hline Deposit & Forecasted reserves (mln. tons) & Explored reserves (mln. tons) \\
\hline Teniz-Corzhunkolskiy & 2243 & 355 \\
\hline Borly & 1760 & 478 \\
\hline Cuucheku & 3140 & 636 \\
\hline Mycubinskiy & 5500 & 3647 \\
\hline
\end{tabular}

Table 3 presents the results of calculating the forecasted differentiated resources according to formula (2) for the coal formations of the Karaganda coal basin that we have already calculated according to the data of electrical prospecting and seismic survey.

Forecasted differential coal reserves of the main suites of the Karaganda coal basin

\begin{tabular}{|c|c|c|}
\hline Strata & $\begin{array}{c}\text { Differentiated stocks } \\
(\%) \text { byv }(\mathrm{m} / \mathrm{s})\end{array}$ & $\begin{array}{c}\text { Differentiated stocks } \\
(\%) \text { by }(\text { Ohm } \cdot \mathrm{m})\end{array}$ \\
\hline Dolinskaya & 14,6 & 14,2 \\
\hline Tentekskaya & 15,1 & 14,5 \\
\hline Karagandinskaya & 14,4 & 14,3 \\
\hline Ashlyarikskaya & 13,6 & 13,4 \\
\hline
\end{tabular}

It can be seen that both methods are in good agreement with each other within the experimental error, which speaks in favor of the proposed model.

\section{Shubarkol coal deposit and its forecasted reserves}

The Shubarkol deposit (Fig. 1) is an asymmetric trough, curved in a sublatitudinal direction with the largest axes of 15.0 and $6.5 \mathrm{~km}$ with an area of $702 \mathrm{~km}^{2}$.

The maximum immersion of carbonaceous deposits is of the order of $250 \mathrm{~m}$. The greatest angles of incidence of the coaliferous stratum from $10-25^{\circ}$ to $30-35^{\circ}$ at the outcrops of coal horizons are in the north and south of the field. The most steep are the north-west and south-eastern parts.

The western and eastern wings lie more hollow $\left(10-20^{\circ}\right)$. The internal structure of the trough is simple with angles of incidence of 3-5 ${ }^{\circ}$. Disjunctive disorders within its limits have not been established.

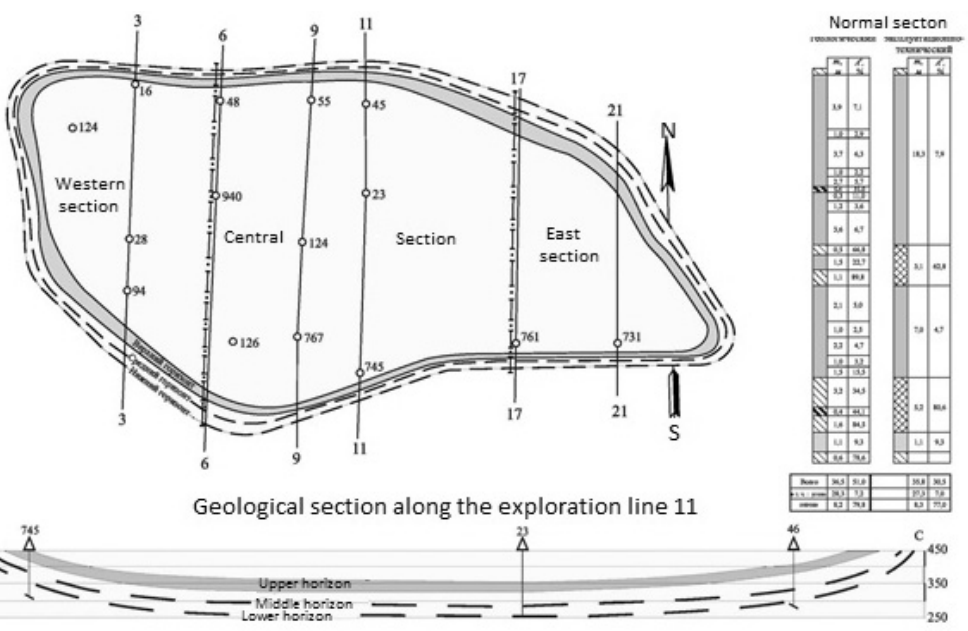

Figure 1. Shubarkol's field. Map of outcrops of coal horizons 
The industrial coal deposit of the deposit is confined to the lower part of the Jurassic section and contains three upper, middle and lower coal horizons.

The most interesting is the Upper Coal Horizon, which is widespread in the trough, is the most powerful, stable, has a relatively simple structure and is adopted for open development. The area with the simplest structure extends 1,5-2,0-kilometer strip from the north-western lock of the trough along the north wing of the fold to the exploration line 10 and belongs to the coal-accumulation unit.

Within its limits, the center of coal accumulation is clearly distinguished, where the horizon is a single monolithic deposit with a structure that is occasionally more complicated in individual excavations. In the center of coal accumulation, division of the horizon into two coal layers $2 \mathrm{~B}$ and $1 \mathrm{~B}$ is seen (Fig. 2). Plast 2B is distributed over $60 \%$ of the area of the deposit and is the most powerful in the horizon (up to $22 \mathrm{~m}$ ). It is composed of 3-5 coal packs with a thickness of $0.4-8.0 \mathrm{~m}$, separated mainly by thin interlayers of mudstones and siltstones $(0.03-0.50 \mathrm{~m})$.

A. By total capacity

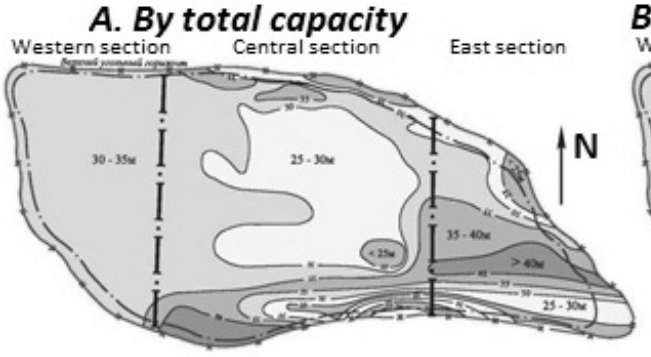

\section{By capacity of internal stripping}

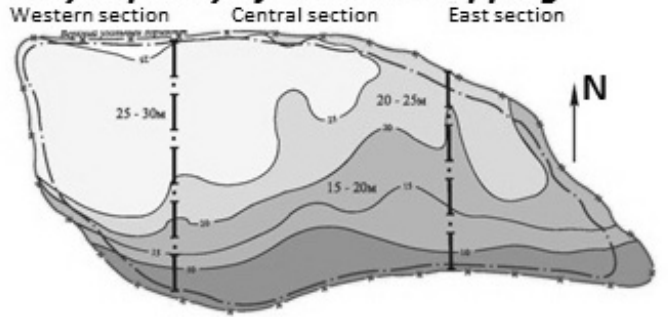

\section{B. By working thickness of a coal}
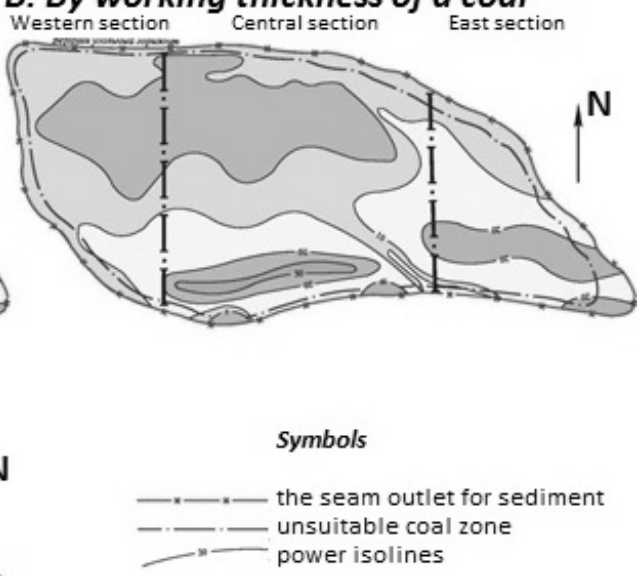

Figure 2. Zoning of the Upper horizon by power

The $1 \mathrm{~B}$ reservoir is traced by a 2.5-3.0-kilometer strip from the south-west to the northeast in the central part of the trough. The thickness of the reservoir is 6-9 $\mathrm{m}$ and is composed of 1-2 packs of coal in the western part of the deposit and 2-5 in the eastern part. In the southern direction, an increase in the number of coal seams occurs and a regular decrease in the working thickness of the formation is observed. The Seam is related to the seasoned.

The coal of the Shubarkol deposit belongs to the long-coal coals of grade D. with the heat of combustion from 5200 to $5700 \mathrm{kcal} / \mathrm{kg}$. The industrial reserves of coal of the Shubarkol field are estimated at over 1.5 billion tons.

We now estimate the predicted reserves of the Shubarkol deposit according to formula (2), using as the physical quantity A the heat of combustion of the Shubarkol coal.

The coefficient $q$ in formula (2) was calculated by the method of [10] and turned out to be $2.16 \times 10^{-4}$. Taking the average value of the calorific value $5450 \mathrm{kcal} / \mathrm{kg}$, we obtain from the formula (2) the differentiated reserves of $P_{d}-14.7 \%$.

The average depth of occurrence of the coal seams of the Shubarkol's field is $250 \mathrm{~m}$. The total volume of the Shubarkol field will be $180 \cdot 109 \mathrm{~m}^{3}$. deposit:

Knowing all these values, using the formula $P=P_{d} \bullet V$, we find the predicted reserves of the Shubarkol

$$
P=2,58 \text { bill. tons. }
$$

The Shubarkol coal field was discovered in 1985, and its industrial development was started already in 1989. Detailed reconnaissance with calculation of reserves was not made. According to some sources (see, for example, [13]) the reserves of the Shubarkol deposit are estimated as over 1.5 billion tons. 
The lack of detailed geological prospecting data is associated with the high cost of drilling operations and the subsequent chemical analysis of core and reservoir samples. If the standards are followed, at least 70,000 wells with a depth of at least 120 meters should be drilled in the Shubarkolsky field. To date, the cost of one running meter of a borehole costs 20 thousand tenge or more, and the cost of a chemical analysis of one sample is 16 thousand tenge or more. It is clear that the costs of a full geological survey and the calculation of the Shubarkol field's reserves will amount to an impressive amount.

\title{
Conclusion
}

The approach proposed at that work when estimating the forecasted reserves of mineral deposits allows a sharp reduction in the volume of geological exploration work during their geological mapping. This allows us to judge, at the stage of preliminary geological exploration of the field, the prospects of its further development.

\section{References}

1 Овчинников Л.Н. Прогнозная оценка мировых запасов в месторождениях суши / Л.Н. Овчинников // ДАН СССР, 1971. - № 3. - С. 683-686.

2 Методические рекомендации по организации и проведению геолого-минералогического картирования масштабов 1:500 000 и 1:200 000. — СПб.: Изд-во ВСЕГЕИ, 2009. — 280 с.

3 Goovaerts P. Geostatistics for natural resources evaluation / P. Goovaerts. — New York: Oxford University Press, 1997. — $480 \mathrm{p}$.

4 Duke J.H. Geological Interpretation for Resource Modelling and Estimation. Mineral Resource and Ore Reserve Estimation / J.H. Duke, P.J. Hanna // The AusIMM Guide to Good Practice. A.C. Edwards (ed.). Melbourne: The Australasian Institute of Mining and Metallurgy, 2001. - P. 147-156.

5 Guibal D. Variography, a Tool for the Resource Geologist. Mineral Resource and Ore Reserve Estimation-The AusIMM Guide to Good Practice. A.C. Edwards (ed.). Melbourne: The Australasian Institute of Mining and Metallurgy, 2001. — P. 85-90.

6 Рогова Т.Б. Подсчет запасов угольных месторождений / Т.Б. Рогова, С.В. Шаклеин, В.О. Ярков. - Кемерово: Кузбас. гос. техн. ун-т, 2010. - 136 с.

7 Методическое руководство по оценке прогнозных ресурсов твердых полезных ископаемых. - М.: Роскомнедра, ЦНИГРИ, 1992. - 106 с.

8 Методическое руководство по оценке прогнозных ресурсов твердых полезных ископаемых. - В 2 ч. - Ч. 1 . Принципы и методы оценки. - М.-Л., 1989. - 82 с.

9 Марков К.А. Методологические основы составления прогнозно-металлогенических карт масштаба 1: 200000 рудных и потенциально рудных районов / К.А. Марков, М.Г. Харламов, Н.Н. Васильев и др. - СПб.: Изд-во ВСЕГЕИ, $1999 .-86$ с.

10 Портнов В.С. Связь магнитной восприимчивости магнетитовых руд с термодинамическими параметрами и содержанием железа / В.С. Портнов, В.М. Юров // Известия вузов. Горный журнал. — 2004. — № 6. — С. 122-126.

11 Выжва С.А. Использование физических свойств минералов для оценки запасов полезных ископаемых / С.А. Выжва, В.М. Юров, В.С. Портнов, М.В. Рева // Вестн. Караганд. ун-та. Сер. Физика. — 2011. — № 4 (64). — С. $78-87$.

12 Portnov V.S. Prognostic resources of mineral deposits by geophysical methods / V.S. Portnov, V.M. Yurov, S.B. Aliyev et al. // Вестн. РУДН. Серия «Инженерные исследования». — 2012. - № 2. - С. 94-101.

13 Ахметжанов Б.А. Опыт и этапы диверсификации угольного производства АО «Шубарколькомир» / Б.А. Ахметжанов, И.Б. Уметалиев, А.А. Жданкин // Горный журнал Казахстана. — 2011. - № 1. — С. 38-40.

\author{
В.С. Портнов, С.А. Выжва, Н.В. Рева, А.Д. Маусымбаева, В.М. Юров
}

\section{Шұбаркөл көмір кен орнының физикалық қасиеттері және болжам қоры}

\begin{abstract}
Мақалада пайдалы қазбалардың болжамдық қорын бағалау әдістемесі сипатталған. Минералдың сараланған физикалық қасиеттерімен байланысты қорының жалпы формуласы ұсынылды. Физикалық құндылық ретінде геофизикалық зерттеу әдістерінің нәтижелері мен зертханалық жағдайларда негізгі сынамалар мен үлгілер бойынша өлшеу қолданылуы мүмкін. Ұсынылған формула бойынша есептелген қорды салыстыру нәтижелері оң екендігі дәлелденді. Бұл әдіс Шұбаркөл көмір кен орнының қорын бағалау үшін пайдаланылды, алайда оған геологиялық барлау жүргізілмеген. Есептеудің жалпы қоры шамамен 3 млрд тоннаны құрады. Ұсынылған әдіс геологиялық барлау жұмыстарының көлемін қысқартуға және оларды іске асыру шығындарын азайтуға мүмкіндік берді.
\end{abstract}

Кілm сөздер: көмір, кен, болжанған қор көлемі, гравитациялық іздестіру, электрлік барлау, сейсмикалық барлау, минерал. 


\title{
В.С. Портнов, С.А. Выжва, Н.В. Рева, А.Д. Маусымбаева, В.М. Юров \\ Физические свойства и прогнозные ресурсы угольного месторождения Шубарколь
}

\begin{abstract}
В работе описан метод оценки прогнозных запасов месторождений полезных ископаемых. Предложена общая формула, связывающая дифференцированные запасы полезного ископаемого с его физическими свойствами. В качестве физической величины могут быть использованы как результаты геофизических методов разведки, так и измерения в лабораторных условиях на керновых и пластовых пробах. Сравнение запасов, вычисленных по предложенной формуле, но с различными физическими величинами, показало хорошую точность предложенного метода. Метод использован для оценки запасов угольного месторождения Шубарколь, детальная геологическая разведка которого не проведена. Расчет дал суммарные запасы около 3 млрд тонн. Предложенный метод позволяет сократить объем геологоразведочных работ и затраты на их проведение.
\end{abstract}

Ключевые слова: уголь, месторождение, прогнозные запасы, гравиразведка, электроразведка, сейсморазведка, минерал.

\section{References}

1 Ovchinnikov, L.N. (1971). Prohnoznaia otsenka mirovykh zapasov v mestorozhdeniiakh sushi [Predictive assessment of world reserves in land deposits]. DAN SSSR - DAN SSSR, 3, 683-686 [in Russian].

2 Metodicheskie rekomendatsii po orhanizatsii i provedeniiu heoloho-mineralohicheskoho kartirovaniia masshtabov 1:500 000 i 1:200 000 (2009). [Methodological recommendations for the organization and conduct of geological and mineralogical mapping of scales 1: 500000 and 1: 200 000]. Saint Petersburg: Izdatelstvo VSEHEI [in Russian].

3 Goovaerts, P. (1997). Geostatistics for natural resources evaluation. New York: Oxford University Press.

4 Duke, J.H., \& Hanna, P.J. (2001). Geological Interpretation for Resource Modeling and Estimation. Mineral Resource and Ore Reserve Estimation. The AusIMM Guide to Good Practice. Edwards, A.C. (ed.). Melbourne: The Australasian Institute of Mining and Metallurgy.

5 Guibal, D. (2001). Variography, a Tool for the Resource Geologist. Mineral Resource and Ore Reserve Estimation. The AusIMM Guide to Good Practice. Edwards A.C. (ed.). Melbourne: Australasian Institute of Mining and Metallurgy.

6 Rogova, T.B., Shaklein, S.V. \& Yarkov, V.O. (2010). Podschet zapasov uholnykh mestorozhdenii [Calculation of coal reserves]. Kemerovo: Kuzbasskii hosudarstvennyi tekhnicheskii universitet [in Russian].

7 Metodicheskoe rukovodstvo po otsenke prohnoznykh resursov tverdykh poleznykh iskopaemykh (1992). [Methodical Guide for the Assessment of Forecasted Resources of Solid Minerals]. TsNIGRI. Moscow: Roskomnedra TsNIHRI, 106 [in Russian].

8 Metodicheskoe rukovodstvo po otsenke prohnoznykh resursov tverdykh poleznykh iskopaemykh. Ch. 1. Principy I metody otsenki [Methodical Guide for the Assessment of Forecasted Resources of Solid Minerals. Part 1. Principles and methods of evaluation] (1989). [in Russian].

9 Markov, K.A., Kharlamov, M.G., \& Vasiliev, N.N. et al. (1999). Metodolohicheskie osnovy sostavleniia prohnoznometallohenicheskikh kart masshtaba 1: 200000 rudnykh I potentsialno rudnykh raionov [The methodological basis for the compilation of prognostic-metallogenic maps at a scale of 1: 200000 ore and potentially ore areas]. Saint Petersburg: Izdatelstvo VSEHEI [in Russian].

10 Portnov, V.S., \& Yurov, V.M. (2004). Sviaz mahnitnoi vospriimchivosti mahnetitovykh rud s termodinamicheskimi parametrami i soderzhaniem zheleza [Relationship of the magnetic susceptibility of magnetite ores with thermodynamic parameters and iron content] Izvestiia VUZov. Hornyi zhurnal - News of universities. Mining Journal, 6, 122-126 [in Russian].

11 Vyzhva, S.A., Yurov, V.M., Portnov, V.S., \& Reva, M.V. (2011). Ispolzovanie fizicheskikh svoistv mineralov dlia otsenki zapasov poleznykh iskopaemykh [Use of physical properties of minerals for the estimation of mineral reserves]. Vestnik Karahandinskoho universiteta. Seriia Fizika - Bulletin of the Karaganda University, Physics, 4 (64), $78-87$ [in Russian].

12 Portnov, V.S., Yurov, V.M., \& Aliyev, S.B. (2012). Prognostic resources of mineral deposits by geophysical methods. Bulletin of the Peoples' Friendship University of Russia, Engineering Surveys, 2, 94-101 [in Russian].

13 Akhmetzhanov, B.A., Umetaliev, I.B., \& Zhdankin, A.A. (2011). Opyt i etapy diversifikatsii uholnoho proizvodstva AO «Shubarkolkomir» [Experience and stages of diversification of coal production of Shubarkolkomir JSC]. Hornyi zhurnal Kazakhstana - Mining Journal of Kazakhstan, 1, 38-40 [in Russian]. 